\author{
Anna Wierzbicka \\ Australian National University, School of Literature, Languages, and Linguistics \\ (Australia, Canberra) \\ anna.wierzbicka@anu.edu.au
}

\title{
THE MEANING OF THE CHRISTIAN CONFESSION OF FAITH: EXPLAINING THE NICENE CREED THROUGH UNIVERSAL HUMAN CONCEPTS
}

This paper is part of a larger project, aiming at re-thinking Christian faith through universal human concepts, and at the same time exploring the scope of possible human understanding, across languages and cultures. Semantics can be divided into three main branches: lexical semantics, grammatical semantics and "textual semantics." The first is concerned with the meaning of words, the second with the meaning of grammatical constructions, and the third with the meaning of entire texts. This paper belongs to the third kind, as its purpose is to explicate the meaning of a text, or, more precisely, part of a text. The text in question, the 'Nicene Creed,' is a fixed text articulating the core of Christian belief, agreed upon in its Greek version at two great councils of the Church in the fourth century, Nicaea in 325 and Constantinople in 381, when the Church was still undivided. It is a text which to this day expresses the common faith of Christians in Western and Eastern Christianity. The paper seeks to "unpack" the meaning of the opening lines of the Nicene Creed: "I believe in one God, Father almighty, maker of heaven and earth, of all things visible and invisible." It relies on the methodology known as NSM (from Natural Semantic Metalanguage). The three semantic texts arrived at in the paper present the meaning of the opening lines of the Creed in words, phrases and sentences which are simple, clear, and universally cross-translatable.

Keywords: Christianity, God, Nicene Creed, Natural Semantic Metalanguage, textual semantics, "meaning $\rightarrow$ text", universal human concepts, Moscow Semantic School, intermediate concepts.

\section{Introduction: Understanding other people's "dreamings"}

Semantics can be divided into three main branches: lexical semantics, grammatical semantics and "textual semantics." The first is concerned with the meaning of words, the second with the meaning of grammatical constructions, and the third with the meaning of 
entire texts. This paper belongs to the third kind, as its purpose is to explicate the meaning of a text, or, more precisely, part of a text. The text in question, the 'Nicene Creed,' is a fixed text articulating the core of Christian belief, agreed upon in its Greek version at two great councils of the Church in the fourth century, Nicaea in 325 and Constantinople in 381, when the Church was still undivided. It is a text which to this day expresses the common faith of Christians in Western and Eastern Christianity.

The idea that not only words and phrases but also entire texts can be explicated underlies "The Story of God and People in Minimal English," which is a core part of my book What Christians Believe [Wierzbicka 2019a]. Since that 'story' and that book provide the background for my present exploration of the meaning of the Nicene Creed, I will begin with three points which I made at the launch of What Christians Believe at the Australian National University in May 2019, and which, as I said then, and say again now, mean a great deal to me.

The first point is that I think it is important to understand other people, those near us, and also those distant from us, whether in space, time, language, or culture. And it is not easy to understand other people, especially if they are distant from us.

I'd like to illustrate this with something that an old Aboriginal man once said to the Australian anthropologist W.H. Stanner: "White man got no dreaming." I have often thought about these words. I'd like to understand fully what this man meant.

On one level, it seems to me that I do understand; and I'd like to respond: Christians do have a dreaming. But on another level, this old man was clearly referring to the $\mathrm{Ab}-$ original concept expressed in words like "Jukurrpa" in Warlpiri, or "Altyerre" in Arrernte.

Stanner tried to explain this concept by speaking of "a sacred, heroic time of the indefinitely remote past, which is also, in a sense, still part of the present" [Stanner 2003: 57]. But for all my admiration for Stanner, this is, it seems to me, a somewhat Eurocentric understanding. This explanation can be very helpful for English speakers, but it relies on concepts which come from English, such as "sacred" and "heroic," not from Australian Aboriginal languages, which have no such words.

As colleagues and I have argued for many years, we can achieve better understanding if in our explanations we rely on concepts which are shared by all languages, and all speakers - concepts like good and bad, word and true, before and after. My colleague Cliff Goddard and I have tried to provide such an explanation of the Warlpiri concept of "jukurrpa" ("dreaming") in an article which was published in Australian Aboriginal Studies [Goddard \& Wierzbicka 2015].

In What Christians Believe, I have tried to provide an analogous explanation of the "Christian dreaming." This is what "The Story of God and People," which is the core of that book, tries to achieve. No doubt, it is not perfect, but I think it is easier to understand than many other books on either theology or comparative religion. And it is far more cross-translatable into other languages.

The second point is that I believe in the essential unity of humankind. This belief is not very fashionable these days in academia and in fact it is often contested, with great emphasis being placed on "diversity" and some scorn expressed for putative 
human universals. Yet without human universals we couldn't have any global ethics, any hope for a global - planetary - conversation about what is good and what is bad. We wouldn't be able to say that it is bad if people want to kill other people, or that it is bad if people want to do very bad things to other people. We can say such things only because, as cross-linguistic investigations show, all languages have words for good and bad, want, do and people.

As Australian Catholic theologian Anthony Kelly puts it in his article "The Risen Christ and Interfaith Dialogue" [Kelly 2012a], "the dialogical attitude $<\ldots>$ envisages unity in difference, rather than a homogenized sameness." I think that as linguists and anthropologists we should adopt the same attitude to human languages and cultures, and to look in them for "unity in difference" rather than either "homogenized sameness" (a la Chomsky) or boundless diversity, without even shared concepts like good and bad, know and think. ${ }^{1}$

As St Paul said to the Greeks in his speech in Athens two thousand years ago, "God hath made of one blood all nations of men $<\ldots>$ to dwell on all the face of the earth" (Acts 17:26, King James Version). "One blood" means here also what anthropologist Franz Boas later called "the psychic unity of mankind." This unity of humankind is also manifested in shared human words like good and bad, know and think, before and after, true, words, and people. Taken together with their shared grammatical frames, these words form a minimal language, both mental and oral, which allows, and underlies human communication. We can call this minimal language "Basic Human."

The third, and last, point that I want to make is about Jesus. Jesus" "dreaming" was universal: he wanted it to reach all people, so his teaching was meant to be accessible to all people. At the same time, it was very much embedded within one particular culture. So there is, seemingly, a paradox here: We can only understand Jesus' teaching in the context of that particular culture, but at the same time, we know that he wanted it to be conveyed also to people from other cultures, as he put it, "to the ends of the earth" (Acts $1: 8)$.

Furthermore, as $21^{\text {st }}$ century speakers of languages like English we are also embedded in a particular culture, which draws, among other things, on Christian concepts, such as "forgiveness," and Christian images, such as "turn the other cheek" and "the good Samaritan." These words and images are shared not only by speakers of English, but also by speakers of a great many other languages. To explain what Christians believe to people from non-Christian backgrounds we need to re-think these concepts and these images with the help of shared human concepts; and also, without relying on norms of interpretation specific to our own culture.

For those who are not interested in Christianity as such, this project of re-thinking Christianity from a universal point of view can work as a laboratory for exploring the scope of possible human understanding. The diversity of human languages and cultures

${ }^{1}$ The universality of know and think was questioned in relation to Australian Aboriginal language Dalabon by Nicholas Evans [2010]. Evans' arguments on this point were answered and, I believe, refuted in Goddard and Wierzbicka [2014: 94-99]. 
is phenomenal, but it is not boundless: I believe that with a good methodology, we can better understand other people's "dreamings" and make our own "dreaming" more intelligible to others. I hope that What Christians Believe represents a step in that direction.

\section{Universal human concepts: the heart of "Basic Human"}

At a time when many linguists and anthropologists emphasise the diversity of languages and even question the existence of any language universals [see e.g. Evans \& Levinson 2009], many theologians take the opposite position and stress what human languages share. For example, Timothy Radcliffe (Dominican), in his book What is the Point of Being Christian [Radcliffe 2005: 145] writes: "As Christians, we believe that the unity of the human community is rooted in shared language."

Referring to the book of another Dominican, Herbert McCabe, Law, Love and Language [McCabe 1968], Radcliffe writes: "Cats or cows have a biological unity which means that they are able to interbreed. Human beings have that sort of unity too, since we too can mate with each other. But we are linguistic animals, which means that we are called to a deeper unity. Human unity is founded on our ability to talk to each other. Language is the breakthrough into a new sort of communion" [Radcliffe 2005: 58].

Radcliffe concludes with a statement which I believe has a special relevance for linguists, and semanticists in particular: "Our human vocation is to go on searching for new and deeper ways of belonging together, new ways of speaking, which realise our capacity for communion more profoundly" [Radcliffe 2005: 159]. I think that different people and different professions may have different vocations; but Radcliffe's statement deeply resonates with my own thinking and experience as a semanticist. In seeking to discover common human concepts and to construct a language accessible, in principle, to all people, colleagues and I have sought to realise more profoundly our human capacity for communion, for mutual understanding, across languages and cultures. This is what this paper seeks to demonstrate, with its semantic exploration of the Nicene Creed.

Theologians who talk about our common humanity and our "shared language" often appear to assume that the word "God" is shared by all people and to attach special significance to this [see for example: Sesboüé 1999: 96-97; Rahner 1983: 61-64 quoted by Sesboüé]. In fact, however, both linguists and missionaries know well that there are a great many languages in the world which don't have a word for God. On the other hand, empirical cross-linguistic investigations indicate that all languages have words corresponding to "good," "bad," and "true" - and some 60 others, out of which the concept of "God" (in the Christian sense of the word) can be constructed.

The first article of the Nicene Creed says "I believe in one God." The fact that not all languages have a word corresponding to "God" doesn't mean that this fundamental tenet of Christian faith cannot be expressed in all languages, but it means that finding a way to express it is not simple or straightforward.

This is where semantics (linguistic semantics) comes in. Once we have analysed the meaning of the word "God" and explained it through words which have counterparts in all languages, the concept of "God" can be introduced into any human language - it can 
be labelled either with a loanword or with an indigenous word, but its content can be explained with indigenous words alone. I will show how this can be done in section 4 . First, however, I will present the repertoire of universal human concepts which has emerged from decades of cross-linguistic investigations carried out by many scholars following the NSM approach (where "NSM" stands for Natural Semantic Metalanguage). ${ }^{2}$

At the heart of this repertoire lies a set of 65 universal semantic primes: concepts which, as evidence suggests, can be found in all languages and which cannot be decomposed into simpler concepts. The full set is given in Table 1. A second set, built on the first one, comprises concepts which NSM scholars call "semantic molecules." This set includes concepts like "hands," "fire" and "be born," which can be found as words (often polysemous words) in all languages but which are not semantic primes and can be decomposed into primes. Table 2 includes only a partial list of universal semantic molecules (as they have emerged from cross-linguistic investigations so far). Using the universal semantic primes and molecules, we can, in principle, explain the meaning of any word and any sentence in any language through a paraphrase formulated in natural language. Such paraphrases may not be idiomatic but they can, in principle, be intelligible and cross-translatable.

Generally speaking, all sentences formulated in "Basic Human" are both intelligible and cross-translatable. These two attributes are closely connected, because only crosstranslatable sentences - that is sentences formulated in Basic Human - are so simple (in both vocabulary and grammar) that they can be generally understood.

One example. An excellent recent book for children which tries to explain Christian faith in a way that children could understand, includes the following sentence about Jesus: "The cause of death was $<\ldots>$ by suffocating on the cross" [YOUCAT Foundation]. Despite the authors' best intentions, this is a complex sentence which is neither generally understandable nor universally cross-translatable: not all English-speaking children can understand the word "suffocate" or the phrase "the cause of death"; and not all languages have a verb corresponding to "suffocate," or nouns corresponding to "cause" and "death." The intended meaning, however, can be easily expressed in "Basic Human" as "He died because he couldn't breathe" - a sentence which is both generally understandable and universally cross-translatable.

Semantic primes grouped into 12 categories [Goddard \& Wierzbicka 2018]

\begin{tabular}{|l|l|}
\hline 1 & i, you, someone, something $\sim$ thing, people, body, kind, part \\
\hline 2 & this, the same, other \\
\hline 3 & one, two, much $\sim$ many, little $\sim$ few, some, all \\
\hline 4 & good, bad, big, small \\
\hline
\end{tabular}

2 The exact relationship between the notions "the Natural Semantic Metalanguage," "minimal language," "Minimal English," and "Basic Human" cannot be discussed here for reasons of space [see, however: Wierzbicka 2014; 2019a; 2019b; Goddard 2018]. 


\begin{tabular}{|c|l|}
\hline 5 & think, know, want, don't want, feel, see, hear \\
\hline 6 & say, words, true \\
\hline 7 & do, happen, move \\
\hline 8 & be (somewhere), there is, be (someone/something), (is) mine \\
\hline 9 & live, die \\
\hline 10 & when $\sim$ time, now, before, after, a long time, a short time, for some time, moment \\
\hline 11 & where $\sim$ place, here, above, below, far, near, side, inside, touch \\
\hline 12 & not, maybe, can, because, if, very, more, like \\
\hline
\end{tabular}

Table 2

Selection of proposed universal molecules [Goddard \& Wierzbicka 2018]

\begin{tabular}{|l|l|}
\hline $\begin{array}{l}\text { hands, mouth, eyes, head, ears, nose, face, legs, teeth, fingers, breasts, skin, } \\
\text { bones, blood }\end{array}$ & Body-parts \\
\hline long, round, flat, thin, hard, soft, sharp, smooth, heavy & Physical \\
\hline be on something, at the top, at the bottom, in the middle, in front of, around & Spatial/physical \\
\hline sky, the Earth, sun, moon, stars, ground, during the day, at night & Environmental \\
\hline day & Times \\
\hline water, fire & Fire and water \\
\hline creature, grow, egg, tail, wings, feathers & Biological \\
\hline children, men, women, be born, mother, father, wife, husband & Biosocial \\
\hline wood, stone & Materials \\
\hline know (someone), be called & "Knowing," “naming" \\
\hline hold, make, kill, breathe, sleep, sit, lie, stand, play, laugh, sing & "Doing” \\
\hline
\end{tabular}

In his book Systematic Lexicography, Yuri Apresjan [2000: 225] wrote: "The fundamental similarity between the theories of the Moscow Semantic School and those of Anna Wierzbicka can be seen at a glance." "3aving pointed out some of these fundamental similarities he moves on to point to some important differences. In Systematic Lexicography, Apresjan identifies one key difference: between the ideal of explicating meanings directly via primitives (as in my Semantic Primitives [Wierzbicka 1972]) and the ideal of explicating them indirectly, via "intermediate concepts" (as in his Lexical Semantics [Apresjan 1992]). It will be seen at a glance, however, that semantic texts presented in the present paper do not try to present all meanings exclusively via semantic primes; my colleagues and I have long revised this ideal as too limiting [see e.g. Wierzbicka 1996;

${ }^{3}$ In this sentence Apresjan contrasts the work of the "Moscow Semantic School" with that of the present author, identified by name, whereas in the heading of the section he speaks of "the Polish Semantic School." To clarify, my own key idea of searching for universal semantic primes developed in Semantic Primitives [Wierzbicka 1972] was due to my Polish colleague Andrzej Bogusławski [1963; 1970]. Since the 1980s, I have been working in close intellectual partnership with my Australian colleague Cliff Goddard. Our joint program, which involves many researchers of different nationalities, is generally known under the acronym NSM (from Natural Semantic Metalanguage). 
Goddard \& Wierzbicka 2014a; Goddard 2011; 2018]. The semantic molecules used in the current NSM approach play the role of intermediate concepts. What is distinct about the NSM approach is that, as far as possible, we aim at using in our semantic texts molecules which meet two conditions: first, they are universal (e.g. 'hands,' 'eyes,' 'men,' 'women,' 'fire,' 'water'), rather than language-specific, and second, they have already been explicated in NSM-based work via semantic primes. Nonetheless, universal or not, our "semantic molecules" are akin to the "intermediate concepts" of the Moscow Semantic School; and it is a joy to be able to acknowledge this convergence.

\section{Can believers in different places and at different times profess the same faith?}

In his recent book $A$ Theology of the Presence and Absence of God prominent Catholic theologian Anthony Godzieba [2018: 13] emphasises "the historically-situated nature of all human knowledge, and of faith as well" and adds: "Further, human knowledge, and also faith, is culturally situated: the believer's faith is mediated by the experience of the world and culture in which it is situated" [Ibid.: 14]. Speaking in simple words, he states: "The believer is a someone in a somewhere that is shared with others $<_{\ldots} . .>$ Our faith experience, even when dealing with the transcendent reality that is God, is saturated with presuppositions and norms that are peculiar to our time and place" [Ibid.].

As far as faith experience is concerned, this is no doubt true. But does it mean that the content of faith cannot be articulated in a way independent of the speaker's, or writer's, historical and cultural environment? Godzieba appears to suggest that this is indeed the case, and that, like everyone else, he too belongs to a particular time and place: "the 'somewhere' from which and for which I am writing is Western culture in the second decade of the third millennium" [Godzieba 2018: 15]. I, Anna Wierzbicka, am also writing in the second decade of the third millennium. In contrast to Godzieba, however, I am not writing exclusively "for Western culture"; nor am I writing (exclusively) "from Western culture." At the very least, I am writing for people in all places around the globe where people are able to communicate through a minimal English of just a few hundred words (and associated grammatical constructions).

As for "where I am writing from," this place can be described as being, experientially, within "Western culture" (and more accurately, within Polish and Australian cultures). Conceptually, however, I can be writing from a "place" which is not tied to any particular time or culture. It is a "place" discovered through decades of empirical cross-linguistic investigations and through radical shedding of anything peculiar to English, other "Western" languages, or indeed to languages anywhere, and searching for the conceptual common ground hidden within them all.

For the postmodernist, all human knowledge is of course historically, and culturally, situated. For many contemporary theologians too, the belief in such "situatedness" is something to be taken for granted. For a cross-linguistic semanticist, however, such historical and cultural "situatedness" of everything, including all human concepts, is open to question - and to empirical verification. Wide-ranging cross-linguistic investigations of the last few decades show that in fact, not all human concepts are peculiar to a particular 
time and place [Goddard \& Wierzbicka 2002; Goddard \& Wierzbicka 2014a; 2014b]. One consequence of this discovery - the discovery of universal human concepts - is that it may be possible, after all, to profess "one faith," beyond all the particularities of individual languages and cultures. Specifically, this discovery allows us to address, from a "planetary" rather than "parochial" point of view the central question: what does it mean to say, "I believe in one God"?

\section{4. "I believe in one God"}

In his book The God of Jesus Christ, German Catholic theologian Cardinal Walter Kasper writes:

The confession of faith which all the great churches of the East and the West have had in common from the early Christian centuries down to our own day begins with the statement: Credo in unum Deum, "I believe in one God." This opening sentence is also the foundational statement of the entire creed. $<\ldots>$ As far as their content is concerned, the other statements of the faith speak of many other things besides God: the beginning and the end of the world; the origin, sin, redemption and fulfilment of the human person; the church, its preaching, sacraments and offices. But these many and varied statements are statements of the faith only to the extent that they are related to $\operatorname{God}\langle\ldots>$ God is therefore the sole and unifying theme of theology. God - who is the salvation of the world and the human race - is as it were the one word spoken in the many words of theology. $<\ldots>$ But what does it really mean to say "God"? [Kasper 1982: 1].

A great many answers for this question have been proposed - by theologians, philosophers, and many others - in words tied to particular languages, most commonly, in Latin, French, German or English. Aiming at a "planetary," pan-human point of view we can try to answer these questions relying, as far as possible, on universal human concepts and grammatical frames. Building on my earlier proposals [see e.g. Wierzbicka 2018; 2001] and trying to improve on them, I am proposing the following semantic text:

\section{BELIEVE IN ONE GOD}

\section{I want to say something; I think about it like this: "It is true";}

\section{I know why I think like this; \\ I want to think like this.}

\section{[THERE IS SOMEONE NOT LIKE PEOPLE]}

There is someone not like people. This someone is good.

We can't see this someone.

At the same time we can know some things about this someone,

we can know these things because this someone wants it.

We people are born, we live for some time, after this we die. 
This someone is not like this. This someone is now, always was, always will be.

We people can do bad things.

This someone is not like this. When this someone does something, it is always good.

When we people say something about something, sometimes it is not true.

This someone is not like this. When this someone says something about something, it is always true.

We people can't know everything. We don't know why many things happen as they happen.

This someone knows everything. This someone knows why all things happen as they happen.

\section{[HOW WE PEOPLE CAN THINK ABOUT THIS SOMEONE]}

We can think about this someone like this:

"This someone is above us people, above everything."

At the same time we can all think:

"I can speak to this someone; when I speak to this someone, this someone can hear me." We can know that it is like this:

"This someone loves us. This someone knows us. This someone wants to do good things for us.

We live because this someone wants it.

We live on earth, the earth is here because this someone wants it."

\section{[GOD IS THIS SOMEONE]}

God is this someone. There is no one else like God.

The unusual texture of this semantic text - its lexical and grammatical poverty, repetitiveness, and "granularity" - is a direct consequence of the fact that, with three exceptions, this text explains the meaning of the first article of the Creed using almost exclusively semantic primes. The three exceptions are: the two universal semantic molecules "be born" and "earth" and the word "love," which is decomposable but not universal.

Why is the word "love" used, then, in a semantic text which is supposed to be universally cross-translatable? The reason is that the concept of 'love' (as in "God loves all people") is so central to the meaning of the Creed (and of the New Testament, which it seeks to distil) that trying to avoid it while explaining the meaning of the Creed would not only obscure and complicate the resulting explanation but actually misrepresent the full meaning of the Creed. If we want outsiders to understand the Creed, it is far better, I believe, to use "love" as a "Christian semantic molecule" fundamental to the meaning of the Christian profession of faith. In other words, the verb "to love" is, like "God," a Christian key word. Of course the meaning of this key word and key molecule needs to be explained, but it doesn't need to be explained within the Nicene Creed script. A fuller discussion of this topic is outside the scope of the present paper (see however my paper Love in cross-linguistic perspective, in press). For my present purposes, suffice it to say 
that the verb "to love" in the sentence "God loves all people" can be explicated as follows:

\section{God loves all people.}

God sees all people

God feels something because of this

God wants to do many things because of this; God wants to do good things for all people.

This is not identical with the meaning of "love" in sentences about people, but very close. I presume when people "love" people this includes thinking about them, which doesn't seem applicable to God; but perhaps they do (often) see them "in their mind's eye" - and when they see them, they feel something because of this:

\section{Mary loves John.}

Mary often thinks about John when she thinks about him, she often sees him (not with her eyes) she feels something because of this she wants to do many things because of this; she wants to do good things for him.

The topic cannot be discussed here in any detail, but intuitively, it should be clear that God doesn't need to "think about" people, because God can see them always - in the primary, universal sense of the word "see," which can apply to dreams, visions, and mental images, and which does not require the use of bodily eyes.

The fact that in addition to "God," "love" is the only non-universal concept needed in the explanation of the Creed, is of course highly significant. Both "God" and "love" are fundamental Christian concepts. They are not universal, but they can be introduced into any language through universal human concepts. Once they have been introduced in this way, they can be combined with universal concepts and used as key words for explaining the Christian story and Christian faith.

\section{5. "Father Almighty" or "Father All-Holding"?}

Turning now to the second line of the Creed, that is, the phrase "Father Almighty," I will first say something briefly about the word "Father," and then a little more about the word "Almighty."

As for "Father," it is important to note that like 'mother,' 'father' too is a universal human concept, and that (polysemy aside) all languages have a word for it [Wierzbicka 2016]. There is no problem, then, with the cross-translatability of the word "father," as used in the Creed and as used in the semantic script developed here. As I see it, the question is what else needs to be included in the semantic script to do justice to what the word "Father" stands for in this line of the Creed.

On this point, I would like to quote a few sentences from a book entitled God is Love: The Heart of Christian Faith by Australian theologian Anthony Kelly: 
Needless to say, there is no excuse for the extreme masculinism of much religious language. The sediment of past epochs of patriarchal experience lies thick on our present powers of expression. It tends to make us forget the subversive intimacy of Jesus' invocation of God as "Abba, Father" < . > Despite the modern psychological ambivalence in regard to "father images," along with the feminist criticism of the long history of patriarchy, "Father" in its Christian meaning denotes the primordial and prodigal character of God's love and the freedom in which it acts [Kelly 2012b].

My own view is that in the explanation of the opening lines of the Creed, we cannot get away from the "father image," but we can supplement it with the "mother image." In the proposed semantic text, I have done it by means of the following two lines: "We people can think about God as children think about their father if they know that he loves them, like they can think about their mother if they know that she loves them." Both the father image and the mother image are biblical (cf. e.g. Isaiah 49:15), and they both imply God's love for people. At the same time, I don't think the two images should be presented as completely symmetrical: in a patriarchal society like ancient Israel, it was the father who was seen as being "above" the household. The assumption of the father's "aboveness" was part of that particular culture, but the assumption of God's "aboveness" (i.e. being someone above people) is not restricted to the patriarchal culture of ancient Israel: it is part of the very idea of 'God' as Christians anywhere in the world have understood and understand it. Thus, in this particular case, the "masculinism" of the image of God as 'father' can be defended. Of course God doesn't have a gender, but in being "above all people, above everything" God can be likened to the head of a household in a patriarchal society. To say this is not to defend patriarchal societies, but to recognize facts: in ancient Israel, it was the father, not the mother, who was regarded as the head of the household. ${ }^{4}$

Catholic theologian Walter Kasper opens his book The God of Jesus Christ with a section entitled "the problem of an almighty Father God," in which he writes:

The Christian confession of faith begins with the sentence: "I believe in God, the Father almighty." This statement sums up in a valid and binding way the essential message of Jesus $\langle\ldots>[\mathrm{T}]$ he indeterminate and ambiguous concept "God" is specified and interpreted by the concept "Father."

This interpretation, it must be admitted, hardly makes the God-question any simpler for us today. On the contrary, the statement, so central to the New Testament, that God is the Father of Jesus Christ and the Father of us all, has today become difficult for many to understand and assimilate [Kasper 1982].

Placing the use of the word "Father" in the New Testament and in the Creed in a cultural and historical context, Kasper points out that in that context, the father "represents power and authority as well as gift, goodness, solicitude and aid," noting that "after a long prior history

${ }^{4}$ It is also essential that Jesus taught his disciples to use the word "Father" in his model prayer: "Our Father who art in heaven" (Matthew 6:9). 
this picture of the father has become uncertain to us today." In the semantic text presented here, the word "father" is used alongside the word "mother," to represent, roughly speaking, parental love, whereas the other aspects of the New-Testamental father image are spelled out, explicitly, in additional components couched in universal human concepts. These additional components build not only on the word "father," but on the whole phrase, traditionally rendered in English as "Father Almighty" - a phrase which is misleading in its implications and which does not match the original Greek version of the Nicene Creed.

The New Testament says that God is love (1 John 4:18), but it does not describe God as "almighty" or "omnipotent." We may find such attributions in some translations of the New Testament, but not in the Greek original. And the same applies to the Nicene Creed. The Greek original of the Nicene Creed does not say: "Father Almighty"; rather, it says "Pater Pantokrator" ("Father Pantokrator"). Most experts agree that "pantokrator," as used in the Creed, meant, essentially, "holding everything in his hands." As, for example, German theologian Hildebrecht Hommel noted in 1956 in his book Schöpfer und Erhalter [Hommel 1956], the word pantokrator has two meanings, because the verb kratein, on which it is based, had two meanings: 1) 'to rule,' 2) 'to hold.' Accordingly, pantokrator "signifies not only omnipotens ['all-mighty'] but, to use St Augustine's rendering, omnitenens ['all-holding'], and this sense is recognised through a long series of exegetes down to Peter Lombard [ $12^{\text {th }}$ century], after whom it seems to have been mostly forgotten." [Rose 1957: 317].

Similarly, the Abarim Publications' online Biblical Greek Dictionary states: “Together with the adjective pan meaning 'all' $<\ldots>$ the familiar word pantokrator, lit. all-holder, not 'all-ruler'."

So when "pantokrator" was translated into Latin as "omnipotens," it was a mistranslation, as noted at the time by Christian writers such as Tertullian and St Augustine, who wanted to render it as omnitenens, "all-holding." As Dutch theologian Pieter Smulders [1980: 5-6] puts it, "It is universally recognized that the Latin omnipotens is an infelicitous rendering of the Greek pantokrator." We can see the original meaning of the word "pantokrator" (as used in the Greek original of the Creed) in the Russian version of the Creed, where we hear: "Veruju v odnogo Boga, Otca, Vsederžitelja," that is "I believe in one God, the Father, the All-holding."

The meaning of pantokrator as 'all-ruler' is perfectly consistent with the use of this word in the Septuagint, the $3^{\text {rd }}$ and $2^{\text {nd }}$ century BC translation of the Hebrew Bible into Greek. The Greek-speaking Jewish authors of this translation used the word pantokrator around 180 times: 120 times to render the Hebrew word usually transliterated in Latin as "Sabaoth" (hosts, armies) and around 60 times to render the Hebrew word "Shaddai," whose exact meaning is disputed [Van der Toorn et al. 1999; McLaughlin \& Eisenstein], but it was never combined with the word pater ('father').

Usually, in the Septuagint the word "pantokrator" appeared in the phrase Kyrios Pantokrator ('Lord Pantokrator'). In the New Testament, the word "Pantokrator" was used several times in Revelation, and once, in one of St Paul's letters, in all cases by itself. But early Christian writers started to combine this word with the word "Pater" ('Father'). Two early uses of "Father Pantokrator" ('Pater Pantokrator') can be found in Justin the 
Martyr and in the anonymous Martyrdom of St Polykarp. Apparently, before the $4^{\text {th }}$ century, Christian authors were usually rendering the Septuagint's phrase Kyrios Pantokrator ('Lord Pantokrator') with a formula composed of three words: "God Father Pantokrator"; and only very rarely with the two-word formula: "Father Pantokrator" [Smulders 1980: 5-6; Holland 1973]. And then, the Nicene Fathers codified, as it were, the twoword formula "Father Pantokrator"; and by doing this, they cemented, I think, a new understanding of God, not as a powerful "Lord of hosts" (i.e. supreme ruler of heavenly armies) but as a Father who wants to, and is able to, care for his children.

\section{I believe in one God, THE FATHER ALMIGHTY (pater pantokrator) \\ I want to say something; I think about it like this: 'It is true'; \\ I know why I think like this; \\ I want to think like this.}

\section{[HOW WE CAN THINK ABOUT GOD]}

There is God, one God. God is above us people.

We can think about God like children can think about their father if they know that he loves them,

like they can think about their mother if they know that she loves them.

We can know this: God wants very good things to happen to us.

We can know: if God wants them to happen, they will happen.

We can think like this:

"We live on earth, the earth is in God's hands, everything is in God's hands."

We can all think: "I am in God's hands."

\section{["WITH GOD ALL THINGS ARE POSSIBLE"]}

(cf. Matthew 19:26; cf. Isaiah 14:24-27; 46:9-11)

We people often think like this about something: "We know that this cannot happen";

At the same time, we can know that it is like this:

if God wants something to happen, it can happen, if God says about something: "I want this to happen," it happens,

if God says to someone: "Something very good will happen to you, I want this," it happens.

[WHEN SOMETHING VERY BAD IS HAPPENING TO SOMEONE...] (cf. Matthew 10:29; Luke 21:16-18)

It is never like this: when something very bad is happening to people, God doesn't know it; if these people feel something very very bad, God doesn't feel anything because of this. It is always like this: when something very bad is happening to someone, God knows it; if this someone feels something very very bad, God feels something because of it.

[NOT EVERYTHING HAPPENS ON EARTH AS GOD WANTS] It is not like this: 
when something very bad happens to someone, it happens because God wants it to happen. Many things happen on earth not as God wants.

Sometimes people do very bad things; sometimes very bad things happen to people.

We cannot know now why it is like this; we can know it when we don't live on earth anymore.

\section{[“ALL WILL BE WELL, AND ALL MANNER OF THING WILL BE WELL”]} (Lady Julian of Norwich)

We can think like this:

"We know that God loves all people.

We know that God wants very good things to happen to all people.

We know that at some time everything will be as God wants, that at some time all will be well."

In addition to universal semantic primes, this text includes the universal semantic molecules "children," "father," "mother," "earth," and "hands." All these molecules have been explicated, through primes, in earlier NSM-based work [Goddard \& Wierzbicka 2014a; Goddard 2016; Wierzbicka 2007].

\section{Maker [Creator] of heaven and Earth, of all things visible and invisible}

Moving now to the third segment of the Nicene Creed, I will start with a semantic text, and then I will comment on the words "maker" and "creator."

I believe in one God, the Father almighty, MAKER OF HEAVEN AND EARTH, OF ALL THINGS [BEINGS] VISIBLE AND INVISIBLE

I want to say something; I think about it like this: 'It is true';

I know why I think like this;

I want to think like this.

[BEFORE THERE WAS ANYTHING ANYWHERE...]

Before there was anything anywhere, there was God.

It was like this then: There was nothing — no places of any kind, no living creatures of any kind, no people.

God wanted it to be not like this. Because of this, God wanted many things to happen.

Because of this, God did something.

[WHAT GOD DID]

We can think about it like this:

"God thought like this: 'It is like this now: there is nothing; I want it to be like this: there is something.'

God thought: 'I want it to be something very good.' 
God thought: 'I want there to be places of many kinds, I want there to be living creatures of many kinds.'

At the same time, God thought like this:

'I want there to be living creatures of one kind not like any other, I want them to be like me. I will love them.

I will do very good things for them. They can know me. They can love me.

If they want, they can live with me forever.'

Because God thought like this, God did something."

[WHAT HAPPENED AFTER THIS]

After this, many things happened, as God wanted.

Some of these things happened in a very short time, others were happening for a very long time.

We can't think about it like this:

"Everything happened as God wanted, everything happens now as God wants."

We can think: "God knows what happened, why it happened; God knows what is happening, why it is happening."

We can think: "At some time, everything will be as God wants."

\section{[WHAT WE CAN SEE]}

We can know that it is like this now:

there is the earth, there is the sky;

on earth, there are places of many kinds, there are living creatures of many kinds; there are people;

far from the earth, there is the sun, there is the moon, there are the stars; people can see all this.

We can know that it is like this because God wants it to be like this.

We can think: "It is like this because a very long time ago God said: 'I want it to be like this'."

At the same time, we can think: "It is like this because God wants it to be like this."

\section{[WHAT WE CAN'T SEE]}

We know that we can't know everything, can't see everything.

We can see people, because people have bodies.

We can all think like this: "I have a body, people can see it."

At the same time, we can all think: "There is something else in me, people can't see it."

We can think: "It is like this because God wants it." At the same time, we can think:

"It is like this:

'We people are one kind; there are others of many other kinds; we can't see them.

They are not like living creatures, they don't have bodies, they don't die.

At the same time, they can think, they can speak, they can speak to God'."

When we think like this, we can know that if it is like this, it is like this because God wants it. 
In this semantic text, we encounter, again, the semantic molecule "earth," and also, "creatures," "sun," "moon" and "stars," which are also universal. We do not encounter, on the other hand, words like "create," "creator" and "creation," which are far from universal. Nor do we encounter words like "maker" and "make," even though "maker" has been used for centuries in the English versions of the Nicene Creed.

I will note at this point that the usual English translation of the Greek phrase poietes to uranou kai ge as "maker of heaven and earth" is somewhat misleading. The Greek word poietes as used by the Fathers of the church was polysemous; it could mean "maker" but it could also mean "creator" - a word which is normally used in the English version of the Apostles' Creed. In English, "creator" sounds either foreign or literary (it is a high register word), whereas "maker" is a homely, colloquial word of native Anglo-Saxon origin, and as such it is preferred by most native speakers.

But of course there is a big difference between a mere "maker" and an awe-inspiring "creator." In the Creed, the concept of God as "creator" (in French, créateur, in Russian, Tvorec, etc.) echoes the first sentence of the Bible: "In the beginning God created heaven and earth," which features the Hebrew word "bara." As John Paul II commented in his General Audience (of January 15, 1986), "God the Creator of Heaven and Earth," "The word 'created' is a translation of the Hebrew word bara, which describes an action of extraordinary power whose subject is God alone" [John Paul II 1986]. Crucially, the word bara as used at the beginning of Genesis and as echoed in the Creed, implies "creation out of nothing," what theologians call "creation ex nihilo." There are no such implications in the English words "make" and "maker."

Indeed, the word "maker" tends to imply the use of some material, and it has often been said that the word "maker" in the English version of the Creed invites the image of God as a craftsman. This is reinforced by the use of the word "things" in the same line: "maker of $\langle\ldots>$ all things visible and invisible." There are no such words in the semantic text proposed here: no "make," no "maker," and no "things." The unique and extraordinary power of God's action - creation ex nihilo — is conveyed exclusively through universal words [see Wierzbicka 2019a: chapter 3].

To conclude this section, I will comment on only one other aspect of the chapter on "Creation": the line "If they want, they can live with me forever. If they want." The repetition of the phrase "if they want" may strike the reader as unusual, and unnecessary in a text composed in Minimal English. In fact, however, the repetition of this phrase has profound theological implications. Briefly, it highlights God's radical respect for human freedom, and also God's willingness to become vulnerable and open to disappointment and suffering - two aspects of Christian understanding of God and creation beautifully captured in a poem by Welsh poet and Anglican priest R. S. Thomas, "Making":

And having built it

I set about furnishing it

To my taste: first moss, then grass

Annually renewed, and animals 
To divert me: faces stared in

From the wild. I thought up the flowers

Then birds. I found the bacteria

Sheltering in primordial

Darkness and called then forth

To the light. Quickly the earth

Teemed. Yet still an absence

Disturbed me. I slept and dreamed

Of a likeness, fashioning it.

When I woke, to a slow

Music: in love with it

For itself, giving it freedom

To love me: risking a disappointment [Thomas, 2012].

\section{Concluding remarks}

Semantics is usually described as the study of meaning (especially, the meaning of words); I think, however, that it can also be described as the study of understanding. Looking at it in this way, I see two important tasks before semanticists: first, to learn how to interpret ours own thoughts, so that we can understand them ourselves and make them accessible to others; and second, to learn to understand (and to help others to understand) what other people say. Both these tasks involve an understanding of the meaning of words, but they both extend also beyond words, to larger stretches of speech (and writing). Borrowing from the Russian linguistic tradition, we can link these two complementary perspectives with two correlative terms: the "Meaning $\rightarrow$ Text" perspective and the "Text $\rightarrow$ Meaning" perspective. Obviously, in both these perspectives, meaning is crucial.

In the present paper, the path taken is that from text — indeed, an extended text - to meaning. The text in question is the Nicene Creed, which is of fundamental importance to all Christians, that is, to a very large part of humanity; and the interpretive approach remains, essentially, faithful to that outlined in my 1972 Semantic Primitives. Needless to say, however, the project undertaken here builds on a great deal of previous thinking about meaning, obviously, not just by the author and colleagues (I can't not mention here my closest partner in thinking, Cliff Goddard [see, for example: Goddard \& Wierzbicka 2014b]), but also by those who have gone before us and those who have worked in other parts of the globe.

In particular, I want to pay homage here (not for the first time) to Leibniz, who with his idea of an "alphabet of human thoughts" is in a sense the father of us all; to Andrzej Bogusławski, who as early as 1963 wanted to build linguistic semantics on the fundament of "indefinables" understood as "non-arbitrary and universal elements of content" [Bogusławski 1970: 143; 1963; 2003]; to Aleksandr Zholkovsky and his idea of "elementary semantic units" which are "truly ultimate units of meaning" [Zholkovsky et al. 1961; Zholkovsky 1964]; to Igor Mel'chuk, from the 1960s the leader and the spiritus movens 
of the high-powered "Meaning-Text" approach; and to Yuri Apresjan, whose monumental, half-a-century-long work on meaning we are honouring here today. Since the paper is about what Christians believe, it will, I hope, be understandable that I can't resist the impulse to end with thanking God, too.

\section{References}

Apresjan Y. Lexical Semantics: User's Guide to Contemporary Russian Vocabulary. Moscow, Nauka Publ., 1992. 633 p.

Apresjan Y. Systematic lexicography. Oxford, New York, Oxford University Press, 2000. 304 p.

Bogusławski A. K voprosu o semanticheskom analize, Unpublished in Voprosy Jazykoznanija, published in A note on Apresjan's concept of 'Polish school of semantics', with an appendix, Lingua Posnaniensis, 1963, no. 45, pp. 7-18.

Bogusławski A. On semantic primitives and meaningfulness. Sign, Language and Culture. A. J. Greimas, R. Jakobson, M. A. Mayenowa (Eds.). The Hague, Mouton, 1970, pp. 143-152.

Bogusławski A. A note on Apresjan's concept of 'Polish school of semantics'. With an Appendix. Lingua Posnaniensis, 2003, no. 45, pp. 7-18.

Evans N. Semantic Typology. The Oxford handbook of linguistic typology. Jae-Jung Sung (Ed.). Oxford, Oxford University Press, 2010, pp. 504-533.

Evans N., Levinson S. The myth of language universals: Language diversity and its importance for cognitive science. Behavioral and Brain Sciences, 2009, no. 32 (5), pp. 429-448. DOI:10.1017/S0140525X0999094X

Goddard C. Semantic Analysis: A Practical Introduction. Second Edition. Oxford, Oxford University Press, 2011. 512 p.

Goddard C. Semantic molecules and their role in NSM lexical definitions. Cahiers de lexicologie, 2016, no. 109, pp. 13-36.

Goddard C. (Ed.) Minimal English for a Global World: Improved communication using fewer words. Cham, Palgrave Macmillan, 2018. 299 p. DOI: 10.1007/978-3-319-62512-6

Goddard C., Wierzbicka A. Words and Meanings: Lexical semantics across domains, languages, and cultures. Oxford, Oxford University Press, 2014a. 323 p. DOI: 10.1093/ acprof:oso/9780199668434.001.0001

Goddard C., Wierzbicka A. Semantic fieldwork and lexical universals. Studies in Language, 2014b, no. 38 (1), pp. 80-126. DOI: 10.1075/sl.38.1.03god

Goddard C., Wierzbicka A. What does Jukurrpa ('Dreamtime', 'the Dreaming') mean? A semantic and conceptual journey of discovery. Australian Aboriginal Studies, 2015, no. 1, pp. 43-65.

Goddard C., Wierzbicka A. Minimal English and how it can add to Global English. Minimal English for a global world: Improved communication using fewer words. C. Goddard (Ed.). Cham, Palgrave Macmillan, 2018, pp. 5-27. DOI: 10.1007/978-3-31962512-6_2 
Goddard C., Wierzbicka A. (Eds.). Meaning and Universal Grammar. John Benjamins, 2002. $356 \mathrm{p}$.

Godzieba A. A Theology of the Presence and Absence of God. Liturgical Press, 2018. $472 \mathrm{p}$.

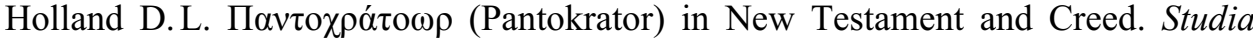
Evangelica, 1973, no. 6, pp. 256-266.

Hommel H. Schöpfer und Erhalter. Berlin, Lettner, 1956. 159 p.

McLaughlin J.F., Eisenstein J.D. Names of God. Available at: www.jewishencyclopedia.com/articles/11305-names-of-god (accessed 28.09.2019)

John Paul II. God the Creator of Heaven and Earth (January 15, 1986). Available at: http://inters.org/John-Paul-II-Catechesis-Heaven-Earth (accessed 20.09.2019)

Kasper W. The God of Jesus Christ. Freiburg, Herder, 1982. 450 p.

Kelly A. The Risen Christ and Interfaith Dialogue. Dreaming A New Earth: Raimon Panikkar and Indigenous Spiritualities. G. Hall, J. Hendriks (Eds.). Melbourne, Mosaic Press, 2012a, pp. 116-126.

Kelly A. GOD IS LOVE: The Heart of Christian Faith. Collegeville, Liturgical Press, 2012b. 137 p.

McCabe H. Law, Love and Language. London, Sheed \& Ward, 1968. 215 p.

Radcliffe T. What is the Point of Being a Christian? London, Burns and Oates, 2005. $218 \mathrm{p}$.

Rahner K. God and Revelation (Theological Investigations Volume 18). New York, The Crossroad Publishing Company, 1983. 312 p.

Rose H. J. REVIEWS Schöpfer und Erhalter by Hilebrecht Hommel. Pp. 159+2 plates. Extract from Theologia Viatorum iv (1952) and v (1953/4) Berlin: Lettner. Journal of Theological Studies, 1957, no. 8 (2), pp. 316-317. DOI: https://doi.org/10.1093/jts/ VIII.2.316

Sesboüé B. Croire: invitation à la foi catholique pour les femmes et les hommes du $x x i^{e}$ siècle. Paris, Droguet et Ardant, 1999. 576 p.

Smulders P. "God Father All-Sovereign": New Testament Use, The Creeds and the Liturgy: An Acclamation? Some Riddles in the Apostles' Creed III. Bijdragen: Tijdschrift voor Filosofie en Theologie, 1980, no. 41, pp. 3-15.

Stanner W.E.H. The Dreaming and other essays. Melbourne, Black Inc. Agenda, 2003. $306 \mathrm{p}$.

Thomas R. S. Collected Poems 1945-1990. London, Hachette, 2012. 539 p.

Van der Toorn K., Becking B., van der Horst P. W. Dictionary of Deities and Demons in the Bible. Leiden, Brill, 1999. 1006 p.

Wierzbicka A. Semantic Primitives. Frankfurt, Athenäum, 1972. 235 p.

Wierzbicka A. Semantics: Primes and Universals. Oxford, Oxford University Press, 1996. $518 \mathrm{p}$.

Wierzbicka A. What did Jesus mean? Explaining the Sermon on the Mount and the Parables in Simple and Universal Human Concepts. New York, Oxford University Press, 2001. 524 p. DOI: 10.1093/0195137337.001.0001 
Wierzbicka A. Bodies and their parts: An NSM approach to semantic typology. Language Sciences, 2007, no. 29, pp. 14-65. DOI: 10.1016/j.langsci.2006.07.002

Wierzbicka A. Imprisoned in English: The hazards of English as a default language. New York, Oxford University Press, 2014. 305 p. DOI: 10.1093/acprof:o so/9780199321490.001.0001

Wierzbicka A. Back to 'Mother' and 'Father' Overcoming the Eurocentrism of Kinship Studies through Eight Lexical Universals. Current Anthropology, 2016, no. 57 (4), pp. 408-429.

Wierzbicka A. Speaking about God in universal words, thinking about God outside English. Religion, Language and the Human Mind. P. Chilton, M. Kopytowska (Eds.). New York, Oxford University Press, 2018, pp. 19-51.

Wierzbicka A. What Christians Believe: The Story of God and People in Minimal English. New York, Oxford University Press, 2019a. 531 p.

Wierzbicka A. From 'Consciousness' to 'I Think, I Feel, I Know': A Commentary on David Chalmers. Journal of Consciousness Studies, 2019b, no. 26 (9/10), pp. 257-269.

YOUCAT Foundation - YOUCAT for kids, Australian Edition. Melbourne, Garrat Publishing, 2019. $210 \mathrm{p}$.

Zholkovsky A. [Introduction]. Mashinnyi perevod i prikladnaia lingvistika, 1964, no. 8, pp. 3-16. (In Russ.)

Zholkovsky A., Leont'eva N.N., Martem'ianov Yu.S. [On the basic use of meaning in machine translation]. Mashinnyi perevod, 1961, no. 2, pp. 17-47. (In Russ.) 